\title{
Effect of organic farming practices on soil and performance of soybean (Glycine max) under semi-arid tropical conditions in Central India
}

\author{
S. B. Aher ${ }^{* 1,2}$, B. L. Lakaria ${ }^{1}$, Swami Kaleshananda ${ }^{2}$, A. B. Singh ${ }^{1}$, S. Ramana ${ }^{1}$, K. Ramesh ${ }^{1}$ \\ and J. K. Thakur ${ }^{1}$ \\ ${ }^{1}$ Indian Institute of Soil Science, Bhopal-462038 (M.P.), INDIA \\ ${ }^{2}$ Ramakrishna Mission Vivekananda University, Narendrapur, Kolkata- 700103 (W.B.), INDIA \\ *Corresponding author. E-mail: satishbaher@yahoo.com \\ Received: September 17, 2014; Revised received: February 6, 2015; Accepted: February 23, 2015
}

\begin{abstract}
A field experiment was conducted to evaluate the influence of organic farming practices on soil health and crop performance of Soybean (Glycine max). The crop cultivar JS-335 of soybean was grown with 30:26.2:16.6 kg $\mathrm{ha}^{-1}$ (NPK) recommended dose of fertilizers under three management practices viz., organic, chemical and integrated (50:50) in randomized block design, replicated three times. Soil organic carbon, available N, P and K, microbial enzymatic activities, total biomass, seed yield and harvest index $(\mathrm{HI})$ were analyzed during the study. It was observed that soil organic carbon $\left(11.3 \mathrm{~g} \mathrm{~kg}^{-1}\right)$, available $\mathrm{N}\left(125 \mathrm{mg} \mathrm{kg}^{-1}\right), \mathrm{P}\left(49.7 \mathrm{mg} \mathrm{kg}^{-1}\right)$ and soil enzyme activities viz., dehydrogenase (DHA) $(98.20 \mu$ grams TPF/g soil/24 h) and alkaline phosphatase $(178.2 \mu$ grams $\mathrm{p}$-nitro phenol/g soil/h) were found significantly higher in the plot managed organically while available $\mathrm{K}\left(320.1 \mathrm{mg} \mathrm{kg}^{-1}\right)$ was not significant with respect to chemical and integrated practices. The total biomass $\left(1927 \mathrm{~kg} \mathrm{ha}^{-1}\right)$ and seed yield $\left(601 \mathrm{~kg} \mathrm{ha}^{-1}\right)$ of soybean was found highest in organic farming practices followed by integrated and chemical practices. Very poor microbial activities were observed in chemically managed plots. Thus, the study demonstrated that the organic farming practice improved soil health and performance of soybean crop.
\end{abstract}

Keywords: Crop performance, Organic farming, Soil environment, Soybean (Glycine max)

\section{INTRODUCTION}

Soybean is the most important grain legume crop in the world in terms of its use in human foods and livestock feeds. In rainy season (July-October), it is the predominant crop in deep Vertisols of Central India (Panwar et al., 2010). Yields of the soybean crop will decrease when essential nutrients are deficient. Chemical fertilizers play an important role to meet nutrient requirement of the crop but their continuous use on lands will have deleterious effects on physical, chemical and biological properties of soil, which in turn reflects on yield (Sarkar et al., 1997). Judicious application of nutrient especially organic manures not only improves the productivity (Sushila and Giri, 2000) but also make cultivation sustainable (Tiwari et al., 2002) because it is the basic source of soil organic matter. Soil organic matter plays pivotal roles in several processes of the soil ecosystem including nutrient cycling, soil structure formation, carbon sequestration, water retention and energy supply to microorganisms (Lakaria et al., 2011). Soil organic matter is the single most important constituent that influences the soil fertility, soil formation, soil biology, physical and chemical properties of soil which in turn reflects in to crop yield (Walker et al., 2004). The long term sustainability and overall productivity of crop are directly related to the maintenance of soil organic matter (Swaroop et al., 2000). The replacement of ancient organic farming due to dynamic developments since generations resulted in decline or stagnation in crop yields is being reported from one part or the other. India is no exception in this regard (Bhandari et al., 2002 and Ladha et al., 2003). Organic farming systems rely on the management of soil organic matter to enhance the chemical, biological and physical properties of soil (Ramesh et al., 2005) The improved soil biological activity is also known to play a key role in suppressing weed pest and diseases (IFOAM, 1998). Greatest challenge in $21^{\text {st }}$ century is to feed the ever increasing population along with the improvement and maintenance of soil health and environmental quality. The present experiment was conducted with an objective to evaluate the influence of organic farming practices on soil health and performance of Soybean (Glycine max) crop.

\section{MATERIALS AND METHODS}

The field experiment was conducted during rainy season (July-October) for two consecutive years of 2011 and 2012 at the research farm of Indian Institute of Soil Science (IISS), Bhopal. The soil of experimental site is clayey in texture (Typic Heplustert), medium in organic carbon, slightly alkaline and non saline with low available nitrogen $(\mathrm{N})$, medium phosphorous $(\mathrm{P})$ and high potassium (K) contents (Table 1). The experiment consists of 
three treatments viz., organic, chemical and integrated (50:50) in randomized block design, replicated three times. The crop cultivar JS-335 of soybean was grown with 30:26.2:16.6 kg ha-1 (NPK) recommended dose of fertilizers. In organic farming practice (OFP), nutrients were applied as cattle dung manure on nitrogen $(\mathrm{N})$ equivalent basis and nutrient requirement of soybean crop.

The nutrient composition of cattle dung manure applied in the experiment is shown in table 2. Phosphorous requirement of soybean was supplemented through rock phosphate. To control weed and pests hand weeding and spray of Neam oil (Azardiractin 0.03\%) was carried out at 30, 45 and 60 days after sowing (DAS) of soybean. In chemical farming practice (CFP), nutrients were supplied through the chemical fertilizers and recommended pesticides were used to control the pests. In integrated farming practice (IFP), 50\% of nutrients were supplied through organic manures and other $50 \%$ were supplied through the chemical fertilizers. Plants were protected by adopting the integrated pest management practices. Soybean was sown at a spacing of $45 \times 5 \mathrm{~cm}$ in the first week of July and harvested in the second week of October. The data was analyzed statistically and treatment means were compared using LSD techniques at 5\% probability appropriate for RBD (Gomez and Gomez, 1984).

Soil samples were collected at harvest (October 2011 and 2012) from soil $0-15 \mathrm{~cm}$ from three spots in each plot. Soil was composited for each replicate, air dried, and ground to pass a 2-mm sieve prior to analysis. Organic carbon was determined by the Walkley and Black (1934) procedure outlined in Prasad (1998). Available nitrogen in soil samples were determined by adapting the alkaline permanganate method of Subbiah and Asija (1956). Available P was determined colorimetrically after the extraction of $1 \mathrm{~g}$ soil with $20 \mathrm{ml} 0.5 \mathrm{M}$ sodium bicarbonate $\left(\mathrm{NaHCO}_{3}\right)$ for a half hour (Olsen et al., 1954). Exchangable potassium was determined using a flame photometer following soil extraction with $1 \mathrm{~N}$ ammonium acetate $\left(\mathrm{COOCH}_{3} \mathrm{NH}_{4}\right)$ (Hanway and Heidel, 1952). Soil enzyme activity viz., dehydrogenase (Casida et al., 1964) and phosphatase (Tabatabai and Bremner, 1969) were estimated to find out the biological activity of the soil.

\section{RESULTS AND DISCUSSION}

Soil organic carbon: Soil organic carbon was significantly greater in the organic farming practice (OFP) $(11.3 \mathrm{mg}$ $\mathrm{kg}^{-1}$ ) than in the chemical farming practice (CFP) and integrated farming practice (IFP) plots (Table 3). Regular organic additions (manures and root biomass) have the largest effect in soil organic matter (Khaleel et al., 1981; Badanur et al., 1990). Tiwari et al. (2002) and Kaur et al. (2005) reported increased soil organic carbon in organic and /or integrated management system compared to chemical management practice. The soil organic carbon was greater in organic and integrated farming practices, which attributed to more carbon going to soil via organic manure addition (Table 2). Manna et al. (2007); Ramesh et al. (2009) and Panwar et al. (2010) reported higher soil organic carbon in the treatments receiving organic nutrients over a long term period. Chang et al. (2014) suggested organic amendment for improving soil organic carbon.

Available N, P and K : Soil available N, P and K were increased with the application of organic manures compared to that of chemical fertilizers. The OFP recorded significantly greater available $\mathrm{N}\left(125 \mathrm{mg} \mathrm{kg}^{-}\right.$ $\left.{ }^{1}\right)$ than IFP (101.8 $\mathrm{mg} \mathrm{kg}^{-1}$ ) and CFP (100.9 $\mathrm{mg} \mathrm{kg}^{-1}$ ) (Table 3). The organic inputs are important source of plant nutrient, especially $\mathrm{N}$, and the supply of $\mathrm{N}$ from applied manures makes an important contribution to the nitrogen demand of growing crops (Abbasi et al., 2007). Similarly, Tiwari et al. (2002) reported the higher available $\mathrm{N}$ in treatments receiving organic inputs. Soil available $P$ was highest in OFP $\left(49.7 \mathrm{mg} \mathrm{kg}^{-1}\right.$ ) compared to IFP and CFP. Addition of organic manures influences $\mathrm{P}$ enrichment in soil (Johnston and Poulton, 1997). The increase in available $P$ might be due to the organic acids, which were released during microbial decomposition of organic matter, which helped in the solubility of native phosphate (Bhardwaj and Omanwar, 1994). The available $\mathrm{K}$ was $320.1 \mathrm{mg} \mathrm{kg}^{-1}, 314.7 \mathrm{mg}$ $\mathrm{kg}^{-1}$ and $314.3 \mathrm{mg} \mathrm{kg}^{-1}$ in OFP, IFP and CFP respectively. The higher $\mathrm{COOCH}_{3} \mathrm{NH}_{4}$-extractable (exchangeable) $\mathrm{K}$ was observed in the OFP and IFP plots than in the CFP plots but it was not significant. Greater $\mathrm{K}$ in organic

Table 1. Characteristics of experimental soil.

\begin{tabular}{|c|c|}
\hline Soil characteristics & $\begin{array}{l}\text { Soil depth } \\
(0-15 \mathrm{~cm})\end{array}$ \\
\hline $\mathrm{pH}$ & 7.86 \\
\hline $\mathrm{EC}\left(\mathrm{dS} \mathrm{m} \mathrm{m}^{-1}\right)$ & 0.52 \\
\hline Organic C $\left(\mathrm{g} \mathrm{kg}^{-1}\right)$ & 5.31 \\
\hline Available $\mathrm{N}\left(\mathrm{mg} \mathrm{kg}^{-1}\right)$ & 68.84 \\
\hline Available P $\left(\mathrm{mg} \mathrm{kg}^{-1}\right)$ & 12.77 \\
\hline Available K (mg kg$\left.{ }^{-1}\right)$ & 265.14 \\
\hline DHA $\left(\mu \mathrm{g} \mathrm{TPFg}^{-1} 24 \mathrm{hrs}^{-1}\right)$ & 52.62 \\
\hline $\begin{array}{l}\text { Alkaline phospatase } \\
\left(\mu \mathrm{g} \mathrm{PNPg}{ }^{-1} 2 \mathrm{hrs}^{-1}\right)\end{array}$ & 83.21 \\
\hline
\end{tabular}

Table 2. Nutrient composition of cattle dung manure applied in the experiment.

\begin{tabular}{lc}
\hline Parameter & Value \\
\hline $\mathrm{pH}$ & 7.54 \\
$\mathrm{EC}\left(\mathrm{dS} \mathrm{m}{ }^{-1}\right)$ & 1.73 \\
Moisture $(\%)$ & 38.67 \\
Total organic carbon $\left(\mathrm{g} \mathrm{kg}^{-1}\right)$ & 195.55 \\
Total Nitrogen $\left(\mathrm{g} \mathrm{kg}^{-1}\right)$ & 8.56 \\
Total Phosphorus $\left(\mathrm{g} \mathrm{kg}^{-1}\right)$ & 4.37 \\
Total Potassium $\left(\mathrm{g} \mathrm{kg}^{-1}\right)$ & 10.67 \\
\hline
\end{tabular}


Table 3. Soil characteristics under different management practices (Mean of 2 years).

\begin{tabular}{lcccc}
\hline Soil characteristics & Organic & Integrated & Inorganic & Mean \\
\hline Organic $\mathrm{C}\left(\mathrm{g} \mathrm{kg}^{-1}\right)$ & 11.3 & 7.1 & 5.4 & 7.9 \\
Available $\mathrm{N}\left(\mathrm{mg} \mathrm{kg}^{-1}\right)$ & 125.0 & 101.8 & 100.9 & 109.2 \\
Available $\mathrm{P}\left(\mathrm{mg} \mathrm{kg}^{-1}\right)$ & 49.7 & 35.2 & 16.5 & 33.8 \\
Available $\mathrm{K}\left(\mathrm{mg} \mathrm{kg}^{-1}\right)$ & 314.7 & 314.3 & 320.1 & 316.4 \\
Dehydrogenase activity $\left(\mu \mathrm{g} \mathrm{TPF} \mathrm{g}{ }^{-1} \mathrm{day}^{-1}\right)$ & 98.2 & 64.4 & 52.6 & 71.7 \\
Alkaline phosphatase activity $\left(\mu \mathrm{g} \mathrm{PPg}^{-1} 2 \mathrm{hr}^{-1}\right)$ & 178.2 & 161.3 & 144.8 & 161.4 \\
\hline
\end{tabular}

Notes. LSD $(P<0.05)$ for organic C: management, 0.39; N: management, 2.62; P: management, 13.29; K: management NS; DHA: management, 14.96; alkaline phosphatase activity: management, 19.99 .

Table 4. Crop productivity under different management practices (Mean of 2 years).

\begin{tabular}{|c|c|c|c|c|}
\hline Parameter & Organic & Integrated & Inorganic & Mean \\
\hline Seed yield $\left(\mathrm{kg} \mathrm{ha}^{-1}\right)$ & 601 & 498 & 426 & 508 \\
\hline Total biomass $\left(\mathrm{kg} \mathrm{ha}^{-1}\right)$ & 1927 & 1807 & 1587 & 1774 \\
\hline Harvest index (HI) (\%) & 31.19 & 27.56 & 26.84 & 28.53 \\
\hline
\end{tabular}

farming practice has been reported earlier by Reganold (1988) and Bulluck et al. (2002) compared to systems receiving mineral fertilizers alone. Panwar et al. (2010) reported higher soil available N, P and K in the plots receiving cattle dung manure applied on nitrogen equivalent basis. The beneficial effect of FYM on available $\mathrm{K}$ is because, besides acting as a source of $\mathrm{K}$, it also release organic collides with grater cation exchange sites that attract $\mathrm{K}$ from the non exchangeable pool and applied $\mathrm{K}$, which ultimately favor the available $\mathrm{K}$ (Majumdar et al., 2005).

Soil enzyme activity: Soil dehydrogenase and alkaline phosphatase activity are dependable on organic carbon content of soil and significantly correlated (Chu et al., 2007). Organic farming practice found the higher enzyme activities for both dehydrogenase $\left(98.2 \mu \mathrm{g}\right.$ TPF $\mathrm{g}^{-1}$ day $\left.^{-1}\right)$ and alkaline phosphatase $\left(178.2 \mu \mathrm{g} \mathrm{PNPg}^{-1} 2 \mathrm{hr}^{-1}\right)$ than integrated and chemical farming practices (Table 3). Lower dehydrogenase activity in soil may be caused by direct toxicity and reduced $\mathrm{pH}$ because of ammonium based fertilizers (Hopkins and Shiel, 1996). Soil enzymes play key biochemical functions in the overall process of organic matter decomposition in the soil system (Burns, 1983; Sinsabaugh et al., 1991) and their activities in the soil are closely related to the organic matter content (Beyer et al., 1993). The application of organic manure results in higher enzyme activity and a positive co-relationship exists between organic manure addition and soil enzyme activities (Manjaiah and Singh, 2001). Okur et al. (2009) and Bowles et al. (2014) reported higher soil enzyme activities under organic farming as compared to the intensively managed farming system.
Seed yield: Soybean seed yield, total biomass and harvest index (HI) was significantly greater in the organic farming practice (OFP) than in the chemical farming practice (CFP) and integrated farming practice (IFP) plots (Table 4). The OFP and IFP recorded significantly higher yield than chemical farming practice. The higher yield was attributed to the higher organic carbon (Walker et al., 2004) and available macronutrients viz., N, P and K. Organic farming practice involves judicious application of nutrient which improved the productivity (Sushila and Giri, 2000). Significant increase in the yield of maize (Ali et al. 2014; Bekeko, 2014), rice (Tedesse et al. 2013) and wheat (Saini and Kumar, 2014) with the application of organic nutrients has already been reported.

\section{Conclusion}

Organic farming systems rely on the management of soil organic matter which has greater influence on soil fertility, soil biology, physical and chemical properties of soil which in turn reflects in to crop yield and sustainability of system. In present investigation, besides the superior performance of rain-fed soybean crop, organic farming practice reported significantly higher organic carbon, available macronutrients and biological activities in the soil.

\section{ACKNOWLEDGEMENTS}

The author is very grateful to Dr. S. Ayyappan, Director General, Indian Council of Agricultural Research (ICAR), Ministry of Agriculture and Cooperation, Govt. of India and Dr. A. Subba Rao, Director, Indian Institute of Soil Science (IISS), Bhopal (M.P.), for their kind permission, guidance and continuous inspiration. 


\section{REFERENCES}

Abbasi, M.K., Hina, M., Khalique, A. and Khan, S.R. (2007). Mineralization of three organic manures used as nitrogen source in a soil incubated under laboratory conditions. Communications in Soil Science and Plant Analysis, 38:1691-1711.

Ali, A., Sharif, M., Wahid, F., Zhang, Z.Q., Shah, S.N.M., Rafiullah, Zaheer, S., Khan, F. and Rehman, F. (2014). Effect of Composted Rock Phosphate with Organic Materials on Yield and Phosphorus Uptake of Berseem and Maize. American Journal of Plant Sciences, 5: 975 984.

Badanur, V.P., Poleshi, C.M. and Naik, B.K. (1990). Effect of organic matter on crop yield, physical and chemical properties of a Vertisol. Journal of the Indian Society of Soil Science, 38: 425-429.

Bekeko, Z. (2014). Effect of enriched farmyard manure and inorganic fertilizers on grain yield and harvest index of hybrid maize (bh-140) at Chiro, eastern Ethiopia. African Journal of Agricultural Research, 9 (7): 663-669.

Beyer, L., Schulten, H.R., Frund, R. and Irmler, U. (1993). Formation and properties of organic matter in forest soils, as revealed by its biological activity, wet chemical analysis, CP-MAS 13C NMR spectroscopy and pyrolysis -field ionization mass spectrometry. Soil Biology and Biochemistry, 25: 587-596.

Bhandari, A.L., Ladha, J.K., Pathak, H., Padre, A.T., Dawe, D. and Gupta R.K. (2002). Yield and soil nutrient changes in a long-term rice-wheat rotation in India. Soil Science Society of America Journal, 66:162-170.

Bharadwaj, V. and Omanwar, P.K. (1994). Long term effects of continuous Rotational cropping and fertilization on crop yields and soil properties-II. Effects on EC, $\mathrm{pH}$, organic matter and available nutrients of soil. Journal of the Indian Society of Soil Science, 42(3): 387-392.

Bowles, T.M., Acosta-Martínez, V., Calderón, F. and Jackson, L.E. (2014). Soil enzyme activities, microbial communities, and carbon and nitrogen availability in organic agroecosystems across an intensively-managed agricultural landscape. Soil Biology \& Biochemistry, 68: 252-262.

Bulluck, L.R., Brosiusb, M., Evanylob, G.K. and Ristainoa, J. B. (2002). Organic and synthetic fertility amendments influence soil microbial, physical and chemical properties on organic and conventional farms. Applied Soil Ecology, 19: 147-160.

Burns, R.G. (1983). Extracellular enzyme-substrate interactions in soil. In: Slater, J.H., Wittenbury, R. and Wimpenny, J. W. T. Eds. Microbes in Their Natural Environment, Cambridge University Press, London, 249-298.

Casida, L.E., Klein, D.A. and Santoro, T. (1964). Soil dehydrogenase activity. Soil Science, 98: 371-376.

Chang, X.F., Zhu, X.X., Wang, S.P., Cui, S.J., Luo, C.Y., Zhang, Z.H. and Wilkes, A. (2014). Impacts of management practices on soil organic carbon in degraded alpine meadows on the Tibetan Plateau. Biogeosciences, 11: 3495-3503.

Chu, H., Lin, X., Fujii, T., Morimoto, S., Yagi, K., Hu, J. and Zhang, J. (2007). Soil microbial biomass, dehydrogenase activity, bacterial community structure in response to long-term fertilizer management. Soil Biology \& Biochemistry, 39: 2971-2976.

Gomez, K.A. and Gomez, A.A. (1984). Statistical procedure for agricultural research. 2nd ed. Singapore: John Wiley and Sons.

Hanway, J.J. and Heidel, H. (1952). Soil analysis methods as used in Iowa State College, Soil Testing Laboratory, Iowa State College Bulletin, 57: 1-131.

Hopkins, D.W. and Shiel, R.S., (1996). Size and activity of soil microbial communities in long-term experimental grassland plots treated with manure and inorganic fertilizers. Biology and Fertility of Soils, 22:66-70.

IFOAM, (1998). IFOAM Basic Standards for organic production and processing, International Federation of Organic Agriculture Movements publications, Tholey-Tholey, Germany.

Johnston, A.E. and Poulton, P.R. (1997). The downward movement and retention of phosphorous in agricultural soils., In: Phosphorus loss from soil to water Eds H. Tunney, O.T. Carton, P.C. Brookes and A.E. Johnston Oxon, CAB International Press UK, 441-445.

Kaur, K., Kapoor, K.K. and Gupta, A.P. (2005). Impact of organic manures with and without mineral fertilizers on soil chemical and biological properties under tropical conditions. Journal of Plant Nutrition and Soil Science, 168:117-122

Khaleel, R., Reddy, K.R. and Overcash, M.R. (1981). Changes in soil physical properties due to organic waste applications: a review. Journal of Environmental Quality, 10:133-141.

Ladha, J.K., D. Dawe, H. Pathak, A.T. Padre, R.L. Yadav, B. Singh, Y. Singh, Y. Singh, P. Pingh, A.L. Kundu, R. Sakal, N. Ram, A.P. Regmi, S.K. Gami, A.L. Bhandari, R. Amin, C.R. Yadav, E.M. Bhattarai, S. Das, H.P. Aggarwal, R.K. Gupta, and P.R. Hobbs. (2003). How extensive are yield declines in long-term rice-wheat experiments in Asia? Field Crops Research, 81:159-180.

Lakaria, B.L., Jha, P. and Biswas, A.K. (2011). Soil carbon dynamics under long term use of organic manures. In: Singh, A.B., Sammi, Reddy, K., Manna, M.C. and Subba, Rao, A. (Eds.), Recycling Organic Wastes for Soil Health and Productivity, Agrotech Publishing Academy, Udaipur, Rajasthan, India, 83-93.

Majumdar, B., Venkatesh, M.S., Kumar, K. and Patiram. (2005). Effect of potassium and farmyard manure on yield, nutrient uptake and quality of ginger in a Typic hapludalf of Meghalaya. Indian Journal of Agricultural Science, 75: 809-811.

Manjaih, K.M. and Singh, D. (2001). Soil organic matter and biological properties after 26 years of maize-wheat -cowpea cropping as affected by manure and fertilization in a cambisol in semiarid region of India. Agriculture, Ecosystems and Environment, 86: 155-162.

Manna, M.C., Swarup, A., Wanjari, R.H., Mishra, B. and Shahi, D.K. (2007). Long-term fertilization, manure and liming effects on soil organic matter and crop yields. Soil \& Tillage Research, 94: 397-409.

Okur, N., Ahmet, A., Muzaffer, C., Selcuk, G. and Huseyin, H. K. (2009). Microbial biomass and enzyme activity in vineyard soils under organic and conventional farming systems. Turkish Journal of Agriculture and Forestry, 33: 413-423.

Olsen, S.R., Cole, C.V., Watanabe, F.S. and Dean, L.A. (1954). Estimation of available $\mathrm{P}$ in soil by extraction with NaHCO3. USDA Circular Nr 939, US Gov.Print. Office, Washington, D.C.

Panwar, N.R., Ramesh, P., Singh, A.B. and Ramana, S. (2010). Influence of organic, chemical and integrated 
management practices on soil organic carbon and soil nutrient status under semi-arid tropical conditions in central India. Communications in Soil Science and Plant Analysis, 41: 1073-1083.

Ramesh, P., Panwar, N.R., Singh, A.B. and Ramana, S. (2009). Production potential, nutrient uptake, soil fertility and economic of soybean (Glycine max)-based cropping systems under organic, chemical and integrated nutrient management practices. Indian Journal of Agronomy, 54 (3): 278-283.

Ramesh, P., Singh, M. and Subba Rao, A. (2005). Organic farming: its relevance to Indian context. Current Science, 88 (4): $561-568$.

Reganold, J.P. (1988). Comparison of soil properties as influenced by organic and conventional farming systems. American Journal of Alternative Agriculture, 3:144 -155 .

Saini, J.P. and Kumar, R. (2014).Long term effect of organic sources of nutrients on productivity and soil health in maize+soybean - wheat+gram cropping system. In Rahmann, G. and Aksoy, U. (Eds.) Proceedings of the 4th ISOFAR Scientific Conference. 'Building Organic Bridges', at the Organic World Congress 2014, 13-15 Oct., Istanbul, Turkey.

Sarkar, R.K., Karmakar, S. and Chakraborty, A. (1997). Response of summer green gram (Phaseolus radiates) to nitrogen, phosphorous application and bacterial inoculation. Indian Journal of Agronomy, 38: 578-581.

Sinsabaugh, R.L., Antibus, R.K. and Linkins, A.E. (1991). An enzymic approach to the analysis of microbial activity during plant litter decomposition. Agriculture, Ecosystems and Environment, 34: 43-54.

Subbiah, B.V. and Asija, G.L. (1956). A rapid procedure for the estimation of available nitrogen in soils. Current
Science, 25: 259-260.

Sushila, R. and Giri, G. (2000). Influence of farmyard manure, nitrogen and biofertilizer on growth, yield attributes and yield of wheat under limited water supply. Indian Journal of Agronomy, 45(3): 590-595.

Swaroop, A., Manna, M.C., Singh, G.B., (2000). Impact of land use and management practices on organic carbon dynamics in soils of India. In: Lal, R., Kimble, J.M., Stewart, B.A. (Eds.), Global Climate Change and Tropical Ecosystems. Advances in Soil Science CRC Press, Boca Raton, FL, pp. 261-281.

Tabatabai, M.A. and Bremner, J.M. (1969). Use of nitrophenyl phosphate assay of soil phosphatase activity. Soil Biology and Biochemiistry, 1: 301-7.

Tadesse, T., Dechassa, N., Bayu, W. and Gebeyehu, S. (2013). Effects of Farmyard Manure and Inorganic Fertilizer Application on Soil Physico-Chemical Properties and Nutrient Balance in Rain-Fed Lowland Rice Ecosystem. American Journal of Plant Sciences, 4: 309-316.

Tiwari, A., Dwivedi, A.K. and Dikshit, P.R. (2002). Longterm influence of organic and inorganic fertilization on soil fertility and productivity of soybean-wheat system in a Vertisol. Journal of Indian Society of Soil Science, 50: 472-475.

Walker, D.J., Clemente, R., Bernal, M.P. (2004). Contrasting effects of manure and compost on soil $\mathrm{pH}$, heavy metal availability and growth of Chenopodium album L. in a soil contaminated by pyritic mine waste. Chemosphere, S7: 215-224.

Walkley, A. and I.A. Black (1934). An examination of the digestion method for determining soil organic matter and a proposed modification of the chromic acid titration method. Soil Science, 37: 29-33. 